\title{
Groin pain in athletes: a novel diagnostic approach
}

\author{
Vijay D. Shetty*, Nikhil S. Shetty, and Amith P. Shetty \\ Hiranandani Orthopaedic Medical Education (HOME), Dr. L. H. Hiranandani Hospital, Hillside Avenue, Hiranandani Gardens, \\ Powai, Mumbai 400076, India
}

Received 18 February 2015, Accepted 20 May 2015, Published online 7 July 2015

\begin{abstract}
Groin pain in a performing athlete can be very challenging to diagnose and treat. The differential diagnosis includes intra-articular causes, extra-articular causes and non-musculoskeletal causes. A detailed clinical and radiological assessment of groin pain in this group is critical and can identify the underlying pathology. Diagnostic hip block is a valuable tool to differentiate intra-articular causes from extra-articular causes. Hip arthroscopy can help in identifying some of the elusive intra-articular conditions, which were once undiagnosed and therefore, left untreated, resulting in premature ending of competitive careers. This article attempts to explore current thinking on evaluation of groin pain, particularly in young individuals, and to establish a simple protocol for a clinical and diagnostic approach to this difficult problem.
\end{abstract}

Key words: Groin pain, Athletes, Diagnosis, Femoroacetabular impingement, Hip arthroscopy.

\section{Introduction}

Groin injuries account for $2 \%$ to $5 \%$ of all sports-related injuries with a high recurrence rate between $15 \%$ and $31 \%$ [1]. Inadequate evaluation of these injuries can result in premature ending of competitive careers [2]. Therefore, proper evaluation and appropriate treatment of groin pain particularly in a competitive athlete are paramount and can be very challenging [3-6]. Groin pain may result from an acute injury or repetitive trauma. Acute groin pain is commonly seen in sports that involve a sudden change in direction while running. In chronic groin pain, the ongoing complaints may be present for months to years [7].

There are no universally agreed guidelines on the clinical and diagnostic approach to recalcitrant groin pain. This article attempts to explore current thinking on evaluation of groin pain, particularly in young individuals, and to establish a simple protocol for a clinical and diagnostic approach to this difficult problem.

\section{Anatomy of groin pain}

The groin consists of the area where the abdomen meets the legs and includes the structures of the perineum. The following structures comprise the groin: lower rectus abdominis musculature, inguinal region, symphysis pubis, upper portions of the adductor muscles of the thigh, the genitalia, as well as the scrotum in males.

\footnotetext{
*Corresponding author: vijaydshetty@gmail.com
}

From an anatomical point of view, various causes of groin pain can be considered under the headings of intra-articular and extra-articular causes $[8,9]$. The intra-articular group consists of lesions arising within the ball and socket of the hip joint, while the extra-articular group includes conditions arising from outside the ball and socket joint [10]. Experts estimate that $60 \%$ of intra-articular injuries are initially misdiagnosed as extra-articular [11]. There have been a number of publications highlighting the presence and importance of these intra-articular injuries [12-14]. It is important to note that many conditions of non-musculoskeletal origin may have referred pain in the groin. These include gynaecological, urological, malignancies, sexually transmitted diseases and rheumatological conditions [15].

\section{Approach to groin pain in athletes}

The approach to athlete with groin pain can challenge the clinician for a variety of reasons as the cause of pain can be intra-articular, extra-articular or radiation from elsewhere [16]. The first step in evaluating the groin pain in young athletes is to obtain a thorough history followed by a detailed physical examination to avoid missing the diagnosis. The key to history taking and the physical examination is to narrow down the differential diagnosis to either intra-articular pain or extra-articular pain.

A history of clicking on movement of the hip may indicate intra-articular pathology like labral tear, loose body or snapping hip. Byrd described the " $\mathrm{C}$ sign" in which a patient cups his or her hand above the greater trochanter in order to describe 


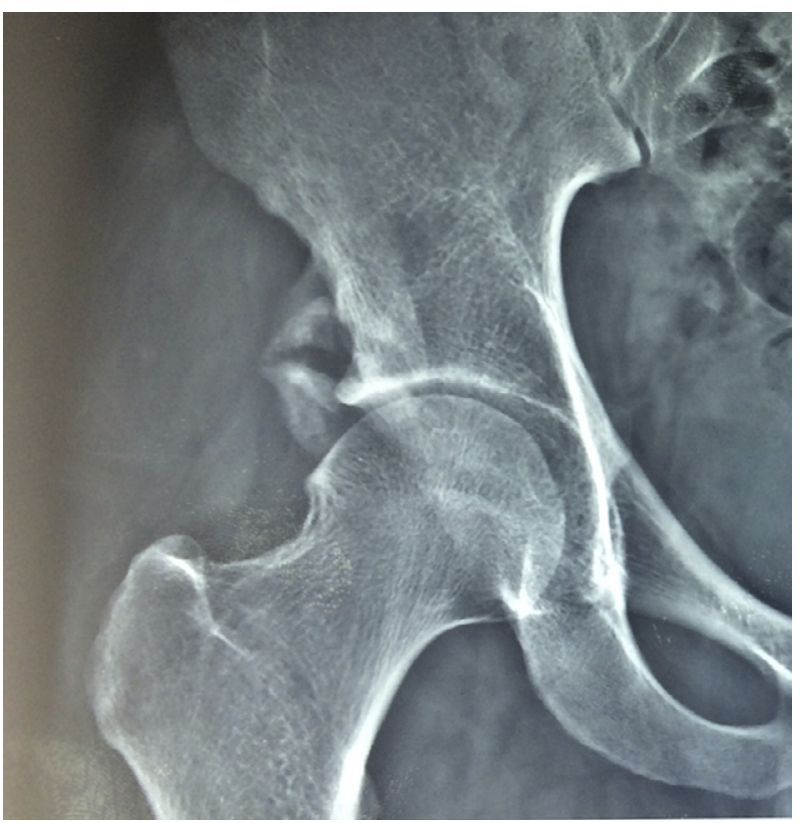

Figure 1. X-ray of right hip showing avulsion fracture of anterior inferior iliac spine in a young footballer.

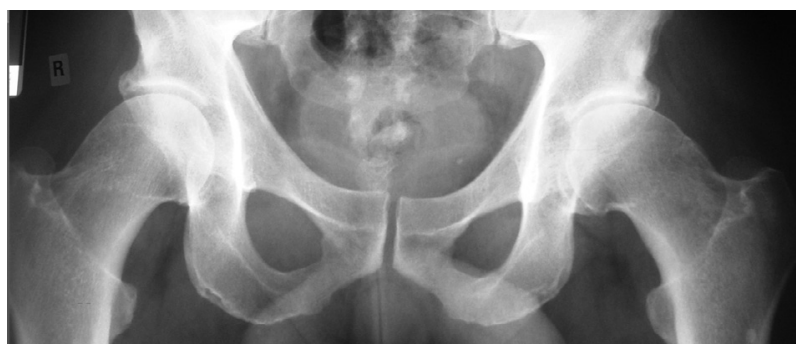

Figure 2. X-ray of the pelvis with both hips showing "pistol-grip" deformity of the proximal femur of both hips indicating "cam" type of impingement.

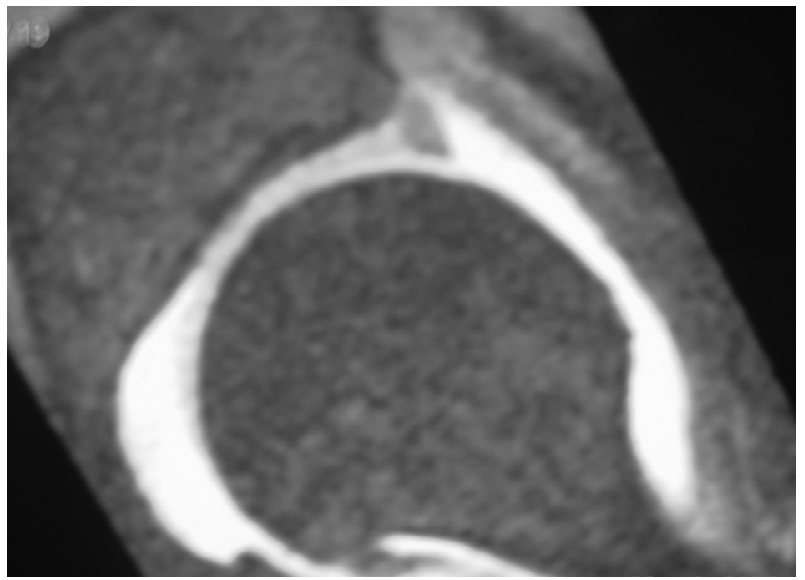

Figure 3. MRI arthrogram of left hip indicating acetabular labral tear.

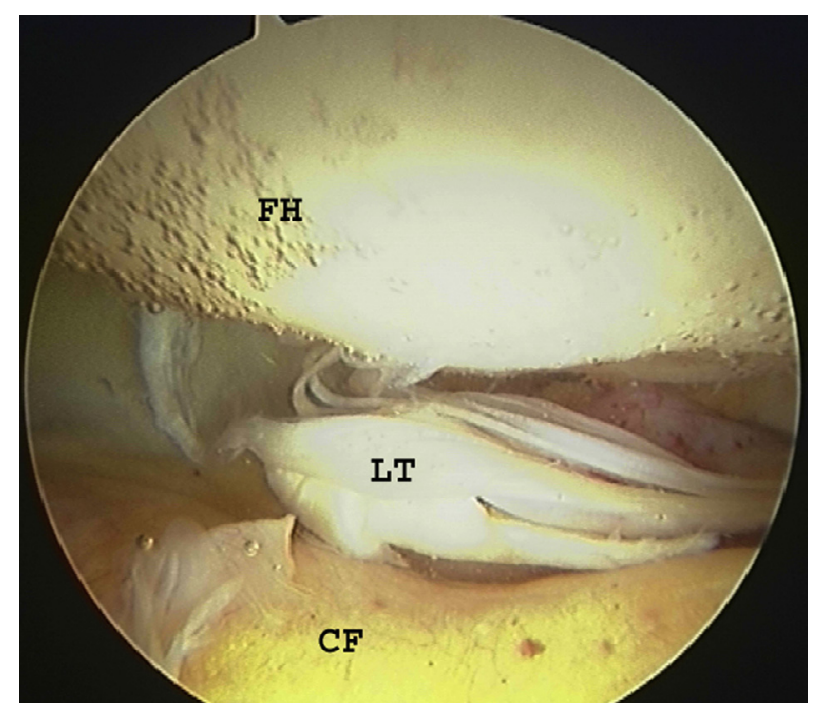

Figure 4. Arthroscopic view of the hip joint demonstrating ligamentum teres injury. $\mathrm{FH}=$ Femoral Head; $\mathrm{LT}=$ Ligamentum Teres; CF $=$ Cotyloid Fossa. CRichard Villar.

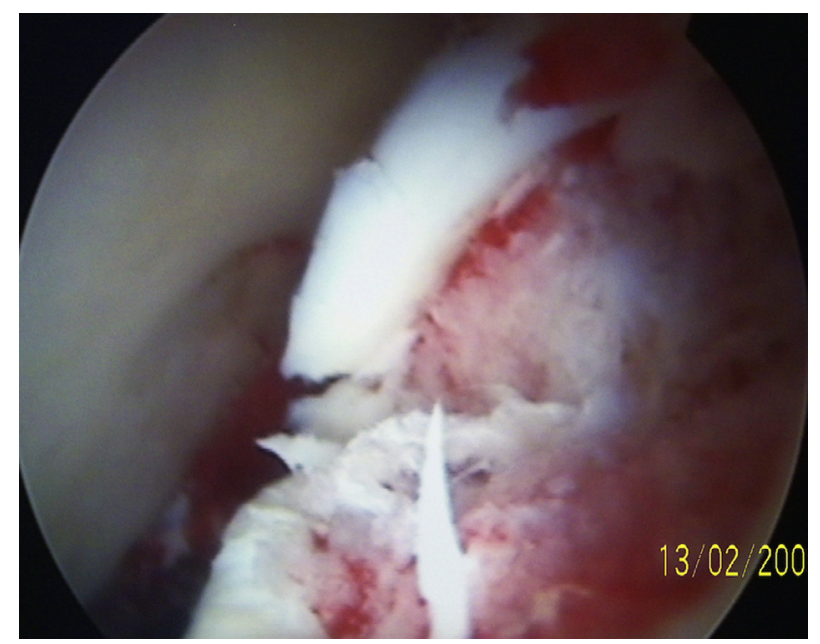

Figure 5. Arthroscopic view of the hip joint demonstrating severe chondral damage of the femoral head in a young man.

deep interior hip pain [8, 17]. Altered sensation or weakness together with a burning-type pain may indicate nerve entrapment. For example, obturator nerve entrapment is an uncommon condition, which causes pain in the region of the adductor muscles.

The physical assessment requires the exposure of as much of the groin and hip as permitted, in standing, supine and lateral position. A detailed examination of hip includes the following: inspection for anatomic irregularity; palpation of specific regions to localise tenderness [18]; assessment of the range of motion of the hip [19]; observation of the patient's gait; and evaluation of performance activities like sprints and jumps which exacerbate the athlete's pain.

Intra-articular pathology usually presents with painful restriction of movements of the hip. It is estimated that 
Table 1. Differential diagnosis for intra-articular causes of groin pain in athletes.

\begin{tabular}{|c|c|c|}
\hline \multicolumn{3}{|c|}{ Common intra-articular pathologies causing groin pain } \\
\hline Conditions & Findings & Related references \\
\hline 1. Femoroacetabular impingement (FAI) & $\begin{array}{l}\text { - Sharp anterior hip pain with deep flexion, internal rotation or abduction. } \\
\text { - Limited internal rotation and adduction in flexion. } \\
\text { - Positive impingement test. }\end{array}$ & {$[17,30,43-48]$} \\
\hline 2. Chondrolabral injuries & $\begin{array}{l}\text { - Dull groin pain, worsens with activities like prolonged sitting, walking. } \\
\text { - Restricted terminal hip range of movements. } \\
\text { - Locking, clicking, giving way. }\end{array}$ & {$[41,49-51]$} \\
\hline 3. Injuries to the ligamentum teres & $\begin{array}{l}\text { - Hip stiffness. } \\
\text { - Giving way. } \\
\text { - Reduced range of motion. }\end{array}$ & {$[52-54]$} \\
\hline 4. Loose bodies & $\begin{array}{l}\text { - Anterior groin pain. } \\
\text { - Catching, locking, clicking or giving way. } \\
\text { - Limited range of movements. }\end{array}$ & {$[55,56]$} \\
\hline
\end{tabular}

Table 2. Differential diagnosis for extra-articular causes of groin pain in athletes.

\begin{tabular}{|c|c|c|c|}
\hline \multicolumn{4}{|c|}{ Common extra-articular pathologies causing groin pain } \\
\hline & Conditions & Findings & Related references \\
\hline 1. & Muscle strain/tears & $\begin{array}{l}\text { - Aching groin or medial thigh pain and may or may not relate a specific } \\
\text { inciting incident. } \\
\text { - Painful restriction of movements especially adduction. } \\
\text { - Localised tenderness and focal swelling along adductors. } \\
\text { - Decreased adductor strength. }\end{array}$ & {$[57,58]$} \\
\hline 2. & Stress fracture & $\begin{array}{l}\text { - Exercise induced pain in hip, groin, thigh or referred to knee that } \\
\text { aggravates at night. } \\
\text { - Sudden worsening of groin pain suggests completion of fracture. }\end{array}$ & [59-63] \\
\hline 3. & Osteitis pubis & $\begin{array}{l}\text { - Anterior hip pain radiating to suprapubic area. } \\
\text { - Localised tenderness over pubic symphysis. }\end{array}$ & {$[57,64,65]$} \\
\hline 4. & Sports hernia & $\begin{array}{l}\text { - Insidious onset of groin pain on activity. } \\
\text { - Pain aggravates on sudden movements like coughing, sneezing, } \\
\text { kicking and sprints. }\end{array}$ & {$[2,15,66,67]$} \\
\hline 5. & Snapping syndromes & $\begin{array}{l}\text { - Groin pain that aggravates on movements. } \\
\text { - Intermittent catching, locking of hip. }\end{array}$ & {$[64]$} \\
\hline 6. & Nerve entrapment & $\begin{array}{l}\text { - Groin pain associated with burning sensation. } \\
\text { - Altered sensation along the distribution of nerve. } \\
\text { - Weakness of affected group of muscles. }\end{array}$ & {$[30,68]$} \\
\hline
\end{tabular}

$27-90 \%$ of patients with groin pain have more than one coexisting injury [13]. Therefore it is possible for clinicians to diagnose and manage one injury, while a second injury may go unrecognised [20, 21]. Extra-articular causes such as osteitis pubis, muscle strain, avulsion injuries, stress fractures and nerve entrapment may be excluded by the type of onset pain and localising the site of tenderness. Acute and chronic causes of groin pain must also be differentiated. Acute injuries are relatively easy to diagnose based on history and physical findings, whereas chronic pain may be due to more than one cause and 


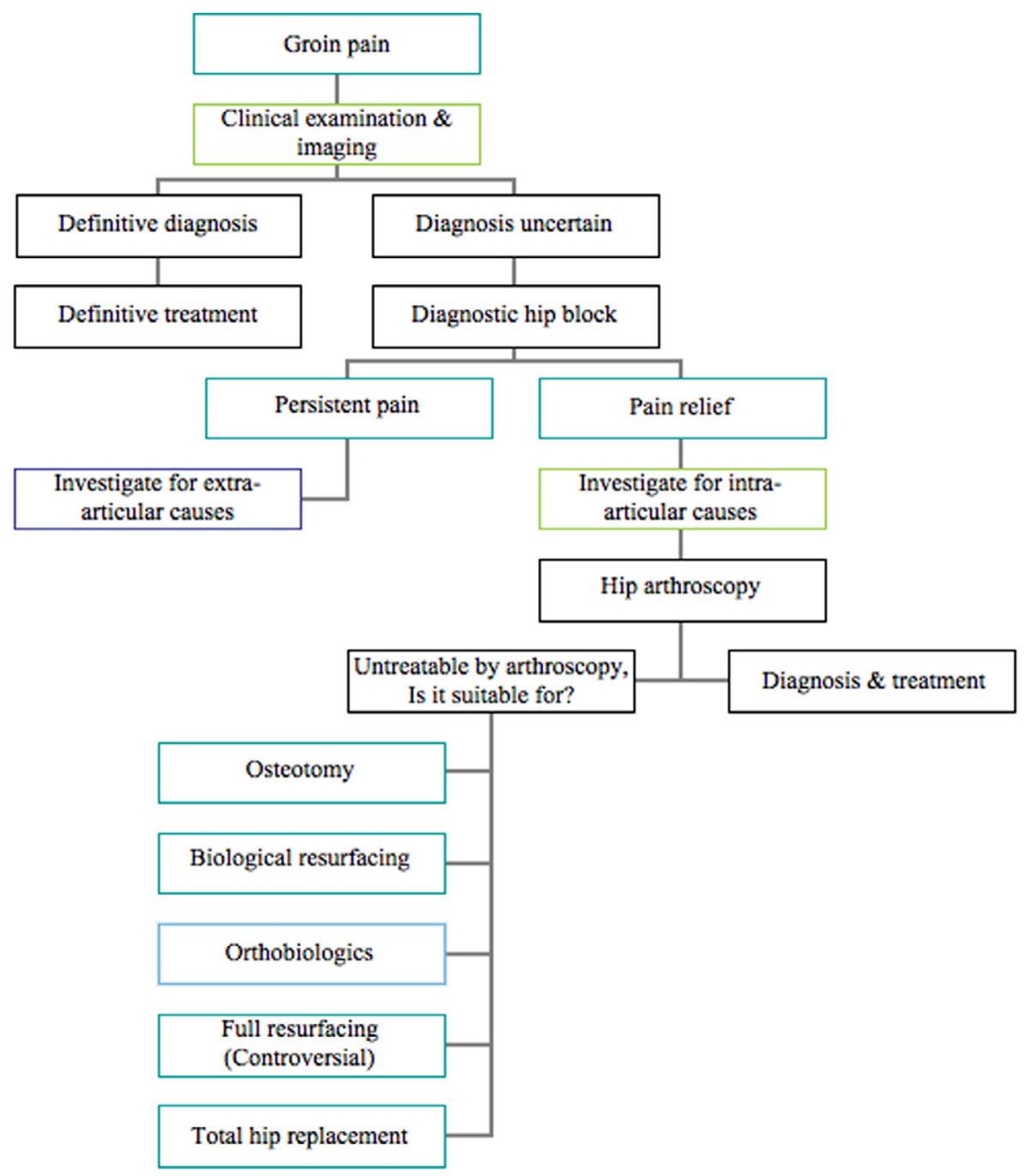

Figure 6. Our novel clinical approach to athletes with groin pain.

often requires additional diagnostic studies. A thorough physical assessment is required to exclude conditions causing referred pain in the groin as in lumbar disc degeneration [22].

\section{Imaging studies}

Plain radiograph of the hip remains the mainstay examination for most of the groin injuries (Figure 1). It remains as a baseline investigation, providing bony definition and alignment (Figure 2). Standardised radiographs are mandatory and should include the use of the correct film-focus distance and proper centring of the X-ray beam to prevent a false impression of altered joint morphology [23].

Ultrasound is a cheap, safe, quick and efficient tool providing exquisite soft tissue detail with the added advantage of providing a dynamic assessment. Dynamic ultrasonography seems to be a promising modality to exclude subtle hernias not detected by physical examination. Ultrasound has been reported to be also useful in diagnosing internal snapping hip syndrome (ISHS) caused by the iliopsoas tendon [16, 24, 25].
Magnetic resonance imaging (MRI) is a powerful tool, providing excellent spatial resolution, and delineation of soft tissue structures including muscles, tendons and cartilage. It is a very sensitive and specific imaging modality for diagnosing osteochondral injuries, soft tissue injuries and inflammation. The use of contrast imaging can further increase the sensitivity of the examination due to enhancement of vascular lesions and in the assessment of avascular necrosis. Many authors advocate MRI combined with arthrography (MRA) of the hip for evaluation of labral pathology (Figure 3) and articular cartilage [26-28].

Multidetector computerised tomography (MDCT) provides excellent bony definition. MDCT 3D reconstruction images can help in surgical planning for bony procedures [29].

\section{Nerve conduction studies}

Nerve conduction studies and electromyography (EMG) are very useful diagnostic tools for potential nerve entrapment syndromes, causing groin pain [30, 31]. 


\section{Diagnostic hip block}

Fluoroscopic guided injections have proven to be an extremely valuable diagnostic and therapeutic test to localise groin pain of intra-articular origin $[32,33]$. This may be done under general anaesthesia to ensure accurate intra-articular placement of the needle and should be followed by a carefully structured physiotherapy assessment in order to establish the intra-articular source of pain. Although the duration and extent of relief are variable, fluoroscopically guided, intra-articular injections of corticosteroid and local anaesthetic should typically alleviate symptoms attributable to labral tears, synovitis, mechanical impingement and osteoarthritic changes. A failed response to a well-placed injection should prompt evaluation for occult, extra-articular sources of symptoms [34]. A positive response to an intra-articular injection has been shown to be a $90 \%$ reliable indicator of an intra-articular abnormality [35]. However, a negative response from an intra-articular hip injection may predict a higher likelihood of having a negative result from surgery [36, 37]. The possibility of communication between the hip joint and iliopsoas bursa may exist and this needs to be assessed with MRI prior to the block [38].

\section{Hip arthroscopy}

Recent years have seen increasing number of hip arthroscopies being performed worldwide. Hip arthroscopy is now a very well-established procedure [39-42]. This endoscopic procedure not only helps to diagnose some of these elusive intraarticular causes of groin pain (Figures 4 and 5) but also helps to treat specific lesions within the joint.

\section{Differential diagnosis for groin pain in athletes}

Table 1 shows the common intra-articular causes for groin pain in athletes with their clinical findings and related references. The common extra-articular causes for groin pain in athletes with their clinical findings and related references are outlined in Table 2. We follow a simple algorithm to approach recalcitrant groin pain in athletes as shown in Figure 6.

\section{Summary}

Groin pain in a performing athlete can be very challenging to diagnose and treat. The differential diagnosis includes intraarticular causes, extra-articular causes and non-musculoskeletal causes. A detailed clinical and radiological assessment of groin pain in this group is critical and can identify the underlying pathology. Diagnostic hip block is a valuable tool to differentiate intra-articular causes from extra-articular causes. Hip arthroscopy can help in identifying some of the elusive intra-articular conditions, which were once undiagnosed and therefore, left untreated, resulting in premature ending of competitive careers.

\section{Conflict of interest}

The authors declare that there is no conflict of interest regarding this article.

Acknowledgement. The authors wish to thank Richard Villar, Cambridge for some of the pictures shown in this article.

\section{References}

1. Werner J, Hägglund M, Walden M, Ekstrand J (2009) UEFA injury study: a prospective study of hip and groin injuries in professional football over seven consecutive seasons. $\mathrm{Br} \mathrm{J}$ Sports Med 43(1), 1036-1040.

2. McSweeney SE, Naraghi A, Salonen D, Theodoropoulos J, White LM (2012) Hip and groin pain in the professional athlete. Can Assoc Radiol J 63(2), 87-99.

3. Schilders E, Bismil Q, Robinson P, O'Connor PJ, Gibbon WW, Talbot JC (2007) Adductor-related groin pain in competitive athletes. J Bone Joint Surg Am 89, 2173-2178.

4. Fricker PA (1997) Management of groin pain in athletes. J Sports Med 31, 97-101.

5. Karlsson J, Sward L, Kalebo P, Thomee R (1994) Chronic groin injuries in athletes, recommendations for treatment and rehabilitation. Sports Med 17, 141-148.

6. Renstrom P, Peterson L (1980) Groin injuries in athletes. Br J Sports Med 14, 30-36.

7. Leunig M, Robertson WJ, Ganz R (2007) Femoroacetabular impingement: diagnosis and management, including open surgical technique. Oper Tech Sports Med 15, 178-188.

8. Byrd JWT (1998) in Operative hip arthroscopy, investigation of the symptomatic hip: physical examination. New York, Thieme. pp. $25-41$.

9. Shetty VD (2008) Persistent anterior hip pain in young adults: current aspects of diagnosis. Hip Int 18(1), 61-67.

10. Nofsinger CC, Kelly BT (2007) Methodical approach to the history and physical exam of athletic groin pain. Oper Tech Sports Med 15, 152-156.

11. Byrd JWT, Jones KS (2001) Hip arthroscopy in athletes. Clin Sports Med 20, 749-762.

12. Ekberg O, Persson NH, Abrahamsson PA, Westlin NE, Lilja B (1988) Longstanding groin pain in athletes, a multidisciplinary approach. Sports Med 6, 56-61.

13. Jagtap P, Shetty G, Mane P, Shetty V (2014) Emerging intra articular causes of groin pain in athletes. Eur J Orthop Surg Traumatol 24(8), 1331-1339.

14. Hoelmich P (1997) Adductor-related groin pain in athletes. Sports Med Arthrosc Rev 5, 285-291.

15. Bradshaw CJ, Bundy M, Falvey E (2008) The diagnosis of longstanding groin pain: a prospective clinical cohort study. Brit J Sports Med 42(10), 551-554.

16. Harmon KG (2007) Evaluation of groin pain in athletes. Curr Sports Med Rep 6, 354-361.

17. Byrd JW (2006) Hip arthroscopy. J Am Acad Orthop Surg 14, 433-444.

18. Braly BA, Beall DP, Martin HD (2006) Clinical examination of the athletic hip. Clin Sports Med 25, 199-210.

19. Martin HD (2005) Clinical examination of the hip. Oper Tech Orthop 15, 177-181. 
20. Morelli V, Weaver V (2005) Groin injuries and groin pain in athletes: part 1. Prim Care 32(1), 163-183.

21. Wettstein M, Mouhsine E, Borens O, Theumann N (2007) Differential diagnosis of groin pain. Rev Med Suisse 3(138), 2882-2884, 2886-2888.

22. Oikawa $\mathrm{Y}$ et al. (2012) Lumbar disc degeneration induces persistent groin pain. Spine (Phila Pa 1976) 37(2), 114-118. PMID: 21270682.

23. Tannast M, Siebenrock KA, Anderson SE (2007) Femoroacetabular impingement: radiographic diagnosis what the radiologist should know. Am J Roentgenol 188(6), 1540-1552.

24. Cardinal E, Buckwalter KA, Capello WN, Duval N (1996) US of the snapping iliopsoas tendon. Radiology 198, 521-522.

25. Janzen DL, Partridge E, Logan PM, Connell DG, Duncan CP (1996) The snapping hip: clinical and imaging findings in transient subluxation of the iliopsoas tendon. Can Assoc Radiol J 47, 202-208.

26. Kassarjian A, Yoon LS, Belzile E, Connolly SA, Millis MB, Palmer WE (2005) Triad of MR arthrographic findings in patients with cam-type femoroacetabular impingement. Radiology 236, 588-592.

27. Kramer J, Recht MP (2002) MR arthrography of the lower extremity. Radiol Clin North Am 40, 1121-1132.

28. Schmid MR, Notzli HP, Zanetti M, Wyss TF, Hodler J (2003) Cartilage lesions in the hip: diagnostic effectiveness of MR arthrography. Radiology 226, 382-386.

29. Perdikakis E, Karachalios T, Katonis P, Karantanas A (2011) Comparison of MR arthrography and MDCT-arthrography for detection of labral and articular cartilage hip pathology. Skelet Radiol 40(11), 1441-1447.

30. Bradshaw C, McCrory P, Bell S, Brukner P (1997) Obturator nerve entrapment: a cause of chronic groin pain in athletes. Am J Sports Med 25, 402-408.

31. McCrory P, Bell S (1999) Nerve entrapment syndromes as a cause of pain in the hip, groin and buttock. Sports Med 27(4), 261-274.

32. Masoud MA, Said HG (2013) Intra-articular hip injection using anatomic surface landmarks, Arthrosc Tech 2(2), e147-e1479

33. Masala $S$ et al. (2010) Diagnostic and therapeutic joint injections. Semin Intervent Radiol 27(2), 160-171.

34. Skendzel JG, Weber AE, Ross JR, Larson CM, Leunig M, Kelly BT, Bedi A (2013) The Approach to the evaluation and surgical treatment of mechanical hip pain in the young patient. J Bone Joint Surg Am 95(18), e133.

35. Byrd JW, Jones KS (2004) Diagnostic accuracy of clinical assessment, magnetic resonance imaging, magnetic resonance arthrography, and intra-articular injection in hip arthroscopy patients. Am J Sports Med 32, 1668-1674.

36. Ayeni OR, Farrokhyar F, Crouch S, Chan K, Sprague S, Bhandari M (2014) Pre-operative intra-articular hip injection as a predictor of short-term outcome following arthroscopic management of femoroacetabular impingement. Knee Surg Sports Traumatol Arthrosc 22(4), 801-805.

37. Mathews J, Alshameeri Z, Loveday D, Khanduja V (2014) The role of fluoroscopically guided intra-articular hip injections in potential candidates for hip arthroscopy: experience at a UK tertiary referral center over 34 months. Arthroscopy 30(2), $153-155$.

38. Wunderbaldinger P, Bremer C, Schellenberger E, Cejna M, Turetschek K, Kainberger F (2002) Imaging features of iliopsoas bursitis. Eur Radiol 12, 409-415.
39. Khanduja V, Villar RN (2007) The arthroscopic management of femoroacetabular impingement. Knee Surg Sports Traumatol Arthrosc 15, 1035-1040.

40. Lubowitz JH, Poehling GG (2006) Hip arthroscopy: an emerging gold standard. Arthroscopy 22, 1257-1259.

41. McCarthy JC, Lee JA (2005) Hip arthroscopy: indications, outcomes and complications. J Bone Joint Surg 87-A, $1138-1145$.

42. Shetty VD, Villar RN (2007) Hip arthroscopy: current concepts and review of literature. Br J Sport Med 41, 64-68.

43. Anderson CN, Riley GM, Gold GE, Safran MR (2013) Hip-femoral acetabular impingement. Clin Sports Med 32(3), 409-425.

44. Ganz R, Parvizi J, Beck M, Leunig M, Notzli H, Siebenrock KA (2003) Femoroacetabular impingement: a cause for osteoarthritis of the hip. Clin Orthop Relat Res 417, 112-120.

45. Guanche CA, Bare AA (2006) Arthroscopic treatment of femoroacetabular impingement. Arthroscopy 22, 95-106.

46. Parvizi J, Leunig M, Ganz R (2007) Femoroacetabular impingement. J Am Acad Orthop Surg 15, 561-570.

47. Philippon MJ, Schenker ML (2006) Arthroscopy for the treatment of femoroacetabular impingement in the athlete. Clin Sports Med 25, 299-308.

48. Shindle MK, Foo LF, Kelly BT, Khanna AJ, Domb BG, Farber A, Wanich T, Potter HG (2006) Magnetic resonance imaging of cartilage in the athlete: current techniques and spectrum of disease. J Bone Joint Surg Am 88(Suppl 4), 27-46.

49. Armfield DR, Towers JD, Robertson DD (2006) Radiographic and MR imaging of the athletic hip. Clin Sports Med 25, 211-239.

50. Tibor LM, Sekiya JK (2008) Differential diagnosis of pain around the hip joint. Arthroscopy 24(12), 1407-1421.

51. Philippon MJ et al. (2009) Arthroscopic findings following traumatic hip dislocation in 14 professional athletes. Arthroscopy 25, 169-174.

52. Byrd JWT, Jones KS (2004) Traumatic rupture of the ligamentum teres as a source of hip pain. Arthroscopy 20, 385-391.

53. Kusma M, Jung J, Dienst M, Goedde S, Kohn D, Seil R (2004) Arthroscopic treatment of an avulsion fracture of the ligamentum teres of the hip in an 18-year-old horse rider. Arthroscopy 20, 64-66.

54. Rao J, Zhou YX, Villar RN (2001) Injury to the ligamentum teres: mechanism, findings, and results of treatment. Clin Sports Med 20, 791-799.

55. Krebs VE (2003) The role of hip arthroscopy in the treatment of synovial disorders and loose bodies. Clin Orthop Relat Res 406, 48-59.

56. Yamamoto Y, Tonotsuka H, Ueda T, Hamada Y (2007) Usefulness of radial contrast-enhanced computed tomography for the diagnosis of acetabular labrum injury. Arthroscopy 23, 1290-1294.

57. Anderson K, Strickland SM, Warren R (2001) Hip and groin injuries in athletes. Am J Sports Med 29, 521-533.

58. Robinson P, White LM (2005) The biomechanics and imaging of soccer injuries. Semin Musculoskelet Radiol 9, 397-420.

59. Davies AG et al. (2010) Review: imaging of groin pain in the athlete. Skelet Radiol 39, 629-644.

60. Mattila VM, Niva M, Kiuru M, Pihlajamaki H (2007) Risk factors for bone stress injuries: a follow-up study of 102,515 person-years. Med Sci Sports Exer 39, 1061-1066. 
61. Pihlajamaki HK, Ruohola JP, Weckstrom M, Kiuru MJ, Visuri TI (2006) Long-term outcome of undisplaced fatigue fractures of the femoral neck in young male adults. J Bone Joint Surg Br $88,1574-1579$.

62. Sofka CM (2006) Imaging of stress fractures. Clin Sports Med $25,53-62$.

63. Spitz D, Newberg A (2002) Imaging of stress fractures in the athlete. Radiol Clin N Am 40, 313-331.

64. Kavanagh EC et al. (2006) MR imaging of groin pain in the athlete [review]. Semin Musculoskelet Radiol 10, 197-207.
65. Omar IM et al. (2008) Athletic pubalgia and "sports hernia": optimal MR imaging technique and findings. Radiographics 28, $1415-1438$.

66. Polglase AL, Frydman GM, Farmer KC (1991) Inguinal surgery for debilitating groin pain in athletes. Med J Aust 155, 674-677.

67. Schilders E (2000) Groin injuries in athletes. Curr Orthop 14, 218-423.

68. Kopell H, Thompson WAL, Postel AH (1962) Entrapment neuropathy of the ilio-inguinal nerve. New Engl J Med 1, $16-19$. 